\title{
Implementation minimal service standards in outpatients hospital district Bogor
}

Case study in Mary Hospital, Cileungsi Hijau and Sentosa hospital, district Bogor

Pelaksanaan Standar Pelayanan Minimal Rawat Jalan pada Rumah Sakit di Kabupaten Bogor (Studi Kasus di Rumah Sakit Mary, Cileungsi Hijau dan Rumah Sakit Sentosa, Parung, Kabupaten Bogor)

\author{
Suminah, Nasser Kelly \\ email: leciputri@gmail.com
}

Health Law Master Program, Soegijapranata Catholic University of Semarang

\begin{abstract}
Minimum Service Standards were made to serve as guidance for regions in organizing hospitals. The standards were then used as working indicators by the hospital management. In the field of health, the Minimum Service Standards were regulated by Health Minister's Decree Nr. 43 of 2016. It was used as a tool to ensure even basic services access and quality to the community that was established and accountable to the Central Government. The Minimum Health Service Standards were very important for hospital's outpatients in relation with the services provided and were closely related to the outpatient's protection.
\end{abstract}

This research applied socio-legal approach having analytical-descriptive specification. The data were gathered by having interviews to some resources, namely Head of Health Office of Bogor District, Director of Mary Hospital of Cileungsi Hijau, Unit Head of Sentosa Hospital of Parung.

The results of the research showed that the Health Minister's Decree Nr. 43 of 2016 on Minimum Service Standards in Health Field had not well implemented. The absence of minimun service standards setting issued by the Local Government, namely Bogor District, had made the health services run the minimum service standards in accordance with the existing regulations that referred to Health Office's Strategic Planning (Renstra) and Health Minister's Regulation on Hospital Classification and Permit. Bogor District should refer to the Health Minister's Decree Nr. 43 of 2016 on Minimum Service Standards in Health Field so that the implementation of minimum services standards to outpatients could be well performed.

Keywords: minimum service standards, outpatient, hospital.

\section{PENDAHULUAN}

Hak atas kesehatan merupakan salah satu Hak Asasi Manusia, sebagaimana diatur dalam Undang-Undang Dasar 1945, dan Pancasila sila ke-5, Keadilan Sosial Bagi Seluruh Rakyat Indonesia. Undang-Undang Dasar Negara Republik Indonesia Tahun 1945 Pasal 28 H ayat (1) juga menyatakan "Setiap orang berhak hidup sejahtera lahir dan batin, bertempat tinggal dan mendapatkan lingkungan hidup yang baik dan sehat serta berhak memperoleh pelayanan kesehatan". Pasal 34 ayat (3) yang menyatakan "Negara bertanggungjawab atas penyediaan fasilitas pelayanan kesehatan dan fasilitas pelayanan umum yang layak."

Undang-Undang No.36 Tahun 2009 tentang Kesehatan, pada konsiderans huruf a menegaskan bahwa kesehatan merupakan hak asasi manusia, dan salah satu unsur kesejahteraan yang harus diwujudkan sesuai dengan cita-cita bangsa Indonesia, sebagaimana dimaksud dalam Pancasila dan UUD Negara RI Tahun 1945. Huruf b 
menuliskan bahwa setiap kegiatan yang dalam upaya untuk memelihara dan meningkatkan derajat kesehatan masyarakat yang setinggi-tingginya, dilaksanakan berdasarkan prinsip non diskriminatif, partisipatif, dan berkelanjutan dalam rangka pembentukan sumber daya manusia Indonesia, serta peningkatan ketahanan dan daya saing bangsa bagi pembangunan nasional. Pelayanan kesehatan diatur dalam Permenkes No.43 Tahun 2016 yaitu Standar Pelayanan Minimal Bidang Kesehatan. Standar Pelayanan Minimal diatur di dalam Undang-Undang No.23 Tahun 2014 tentang Pemerintahan Daerah, Pasal 18 ayat (1).

Permenkes No. 43 Tahun 2016 tentang Standar Pelayanan Minimal Bidang Kesehatan, telah mengatur mengenai Standar yang harus dijadikan acuan dalam pelayanan kesehatan, agar pelayanan yang didapatkan sesuai dengan kebutuhan pasien dan tercapainya sasaran pembangunan nasional bidang kesehatan. Menteri Kesehatan juga telah mengeluarkan surat keputusan No. 129/Menkes/SK/II/2008 tentang Standar Pelayanan Minimal Rumah Sakit, yang didalamnya mengatur tentang standar rawat jalan di rumah sakit. Dalam desentralisasi di bidang kesehatan, pencapaian Visi Indonesia Sehat ditentukan oleh Visi Pembangunan Kesehatan setiap provinsi, yaitu Provinsi Sehat, dan penetapan untuk kabupaten atau kota mengacu pada indikator yang tercantum pada Standar Pelayanan Minimal Bidang Kesehatan.'

SPM digunakan sebagai alat untuk menjamin akses dan mutu pelayanan dasar kepada masyarakat secara merata yang ditetapkan dan dipertanggungjawabkan kepada Pusat. Ini disesuaikan dengan kemampuan kelembagaan daerah yang bersangkutan dengan mengacu pada pedoman yang ditetapkan oleh Mendagri. ${ }^{2}$

\section{Perumusan masalah}

1. Bagaimana pengaturan SPM rawat jalan pada RS Mary dan RS Sentosa di Kab. Bogor ?

2. Faktor-faktor apa saja yang mempengaruhi pelaksanaan standar pelayanan minimal rawat jalan pada rumah sakit di Kabupaten Bogor?

3. Bagaimana pelaksanaan standar pelayanan minimal rawat jalan pada rumah sakit di Kabupaten Bogor?

\section{METODE PENELITIAN}

\section{Metode pendekatan}

Penelitian pada dasarnya merupakan suatu upaya pencarian terhadap pengetahuan yang benar dimana nantinya pengetahuan yang benar ini akan dipergunakan untuk menjawab suatu pertanyaan atau ketidaktahuan akan suatu hal tertentu. ${ }^{3}$

Penelitian ini menggunakan metode pendekatan yuridis sosiologis untuk memberikan penjelasan sejelas-jelasnya tentang perilaku masyarakat terhadap hukum agar pejabat

${ }^{1}$ Ferry Efendi dan Makhfudli, 2009, Keperawatan Kesehatan Komunitas : Teori dan Praktik dalam Keperawatan, Jakarta : Salemba Medika, hlm. 78.

${ }^{2}$ Kemenkes RI, 2017, Inilah Perubahan Standar Pelayanan Minimal (SPM), http://www.depkes.go.id, diakses pada tanggal, 20 Oktober 2017.

${ }^{3}$ Bambang Sunggono, 1997, Metodologi Penelitian Hukum, Jakarta : Rajagrafindo Perkasa, hlm. 28. 
yang berwenang tidak salah dalam mengambil suatu kebijakan dengan landasan teori hukum empiris yang terdapat dalam sosiologi hukum. ${ }^{4}$

Disini hukum dikonsepsikan sebagai suatu institusi sosial yang dikaitkan secara nyata dengan variabel-variabel sosial yang lain, hukum yang secara empiris merupakan gejala masyarakat dipelajari sebagai suatu variabel penyebab (independent variable) yang menimbulkan variabel akibat (dependent variable) pada berbagai kehidupan sosial. ${ }^{5}$

Penelitian juga merupakan suatu sarana (ilmiah) bagi pengembangan ilmu pengetahuan dan teknologi, sehingga metodologi penelitian yang diterapkan harus disesuaikan dengan ilmu pengetahuan yang menjadi induknya. ${ }^{6}$

2. Spesifikasi penelitian : Penelitian ini menggunakan spesifikasi penelitian deskriptif analitis, yaitu untuk mengetahui bagaimana pelaksanaan standar pelayanan minimal rawat jalan pada rumah sakit di Kabupaten Bogor, sehingga akan diperoleh pemahaman ilmiah atas pelaksanaan standar pelayanan minimal bagi perlindungan hukum pasien. ${ }^{7}$

\section{Definisi operasional}

Standar Pelayanan Minimal (SPM) adalah : Ketentuan mengenai jenis dan mutu pelayanan dasar yang merupakan urusan wajib daerah yang berhak diperoleh setiap warga Negara secara minimal.

Tenaga Kesehatan adalah : setiap orang yang mengabdikan diri dalam bidang kesehatan serta memiliki pengetahuan dan/atau keterampilan melalui pendidikan di bidang kesehatan yang untuk jenis tertentu memerlukan kewenangan untuk melakukan upaya kesehatan.

Fasilitas Pelayanan Kesehatan adalah : suatu alat atau tempat yang digunakan untuk menyelenggarakan upaya pelayanan kesehatan, baik promotif, preventif, kuratif maupun rehabilitatif. ${ }^{8}$

Rawat jalan adalah : Pelayanan medis kepada seorang pasien untuk tujuan pengamatan, diagnosis, pengobatan, rehabilitasi, dan pelayanan kesehatan lainnya, tanpa mengharuskan pasien tersebut dirawat inap.

Rumah Sakit adalah : Institusi pelayanan kesehatan yang menyelenggarakan pelayanan kesehatan perorangan secara paripurna yang menyediakan pelayanan rawat inap, rawat jalan, dan gawat darurat.

Perlindungan hukum adalah : Memberikan pengayoman kepada hak asasi manusia yang dirugikan orang lain dan perlindungan tersebut diberikan kepada masyarakat agar mereka dapat menikmati semua hak-hak yang diberikan oleh hukum.

\footnotetext{
${ }^{4}$ I Made Pasek Diantha, 2017, Metodologi Penelitian Hukum Normatif Dalam Justifikasi Teori Hukum, Jakarta : Prenada Media Grup, hlm. 12.

5Soerjono Soekanto dan Sri Mamudji, 2010, Penelitian Hukum Normatif, Jakarta : Rajawali Pers, hlm. 34.

${ }^{6}$ Ronny Hanitijo Soemitro, 1994, Metodologi Penelitian Hukum dan Jurimetri, Jakarta : Ghalia Indonesia, hlm. 1.

${ }^{7}$ Majda El Muhtaj, 2015, Hak Asasi Manusia Dalam Konstitusi Indonesia, Jakarta : Kencana, hlm. 13.

${ }^{8}$ Soekidjo Notoatmodjo, 2010, Etika dan Hukum Kesehatan, Jakarta : Rineka Cipta, hlm. 50.
} 
Pasien adalah : Setiap orang yang melakukan konsultasi masalah kesehatannya untuk memperoleh pelayanan kesehatan yang diperlukan baik secara langsung maupun tidak langsung kepada dokter atau dokter gigi.

\section{Metode pengumpulan data}

1). Data Primer : yaitu data yang diperoleh dilapangan, maka metodologi yang digunakan adalah Wawancara. Wawancara dilakukan kebeberapa pihak, yaitu :

a. Direktur RS Mary, Cileungsi Hijau dan RS Sentosa, Parung, Kab. Bogor.

b. Kepala Unit Rawat Jalan RS Mary, Cileungsi hijau dan RS Sentosa, Parung, Kab. Bogor.

c. Dinas Kesehatan Kabupaten Bogor.

2). Data sekunder : Studi pustaka

1. Bahan Hukum Primer : Bahan hukum primer, bahan hukum yang mengikat dan terdiri atas norma-norma dasar yaitu :

a. Undang-Undang Dasar 1945.

b. Undang-Undang No. 29 Tahun 2004 tentang Praktik Kedokteran.

c. Undang-Undang No. 36 Tahun 2009 tentang Kesehatan.

d. Undang-Undang No. 44 Tahun 2009 tentang Rumah Sakit.

e. Undang-Undang No. 36 Tahun 2014 tentang Tenaga Kesehatan.

f. Permenkes No. 11 tahun 2016 tentang Penyelenggaraan Pelayanan Rawat Jalan Eksekutif Di Rumah Sakit.

g. Permenkes No. 43 Tahun 2016 tentang Standar Pelayanan Minimal di Bidang Kesehatan.

h.Undang-Undang No. 23 Tahun 2014 tentang Pemerintahan Daerah.

2. Bahan hukum sekunder : bahan-bahan yang erat hubungannya dengan bahan hukum primer dan dapat membantu menganalisa dan memahami bahan hukum primer misalnya rancangan peraturan perundang-undangan, hasil karya ilmiah pada sarjana, hasil-hasil penelitian. ${ }^{9}$

5. Metode analisis data : Analisa yang digunakan dalam penelitian ini analisa kualiatif dengan menggunakan teori hukum, asas hukum, dan peraturan perundang-undangan. Metode analisis kualitatif digunakan untuk data yang tidak bisa dihitung. Penelitian ini bersifat deskriptif maka digunakan metode induktif. Metode induktif digunakan karena penelitian ini berangkat dari Standar Pelayanan Minimal di Bidang Kesehatan Pada Pasien Rawat Jalan di Rumah Sakit Mary, Cileungsi Hijau dan Rumah Sakit Sentosa, Parung, Kabupaten Bogor.

${ }^{9}$ Peter Mahmud Marzuki, 2005, Penelitian Hukum, Jakarta : Prenada Media, hlm. 155. 


\section{TINJAUAN PUSTAKA}

\section{Teori Pelaksanaan}

Implementasi adalah sarana untuk melaksanakan sesuatu yang menimbulkan dampak atau akibat terhadap sesuatu.

\section{Teori Implementasi}

Van Meter dan Van Hom : Implementasi adalah tindakan-tindakan yang dilakukan baik oleh individu-individu/pejabat-pejabat atau kelompok-kelompok pemerintah atau swasta yang diarahkan pada tercapainya tujuan yang telah digariskan dalam keputusan kebijakan.

\section{Standar Pelayanan Minimal (SPM)}

SPM adalah ketentuan mengenai jenis dan mutu pelayanan dasar yang merupakan urusan pemerintahan wajib yang berhak diperoleh setiap warga negara secara minimal.

SPM RS Kab/Kota adalah standar pelayanan berdasarkan kewenangan yang telah diserahkan, yang harus dilaksanakan Rumah Sakit Kabupaten/Kota untuk meningkatkan mutu pelayanan yang dapat dijangkau oleh masyarakat yang sekaligus merupakan akuntabilitas daerah kepada pemerintah dalam penyelenggaraan pemerintah Kab/Kota serta sebagai instrumen pembinaan dan pengawasan pemerintah kepada Pemerintah Kabupaten dan Pemerintah Kota.

Moenir adalah : kegiatan yang dilakukan oleh seseorang atau sekelompok orang dengan landasan faktor material melalui sistem, prosedur dan metode tertentu dalam usaha memenuhi kepentingan orang lain sesuai dengan haknya. ${ }^{10}$

Sinambela dkk adalah : sebagai setiap kegiatan yang dilakukan oleh pemerintah terhadap sejumlah manusia yang memiliki setiap kegiatan yang menguntungkan dalam suatu kumpulan atau kesatuan, dan menawarkan kepuasan meskipun hasilnya tidak terikat pada suatu produk secara fisik. ${ }^{11}$

Prinsip pelayanan yang telah ditetapkan dalam Keputusan Mneteri Pendayagunaan Aparatur Negara No. 63/KEP/M.PAN/2003 ada 14 unsur, yaitu:

1. Prosedur pelayanan, yaitu kemudahan tahapan pelayanan yang diberikan kepada masyarakat dilihat dari sisi kesederhanaan alur pelayanan.

2. Persyaratan pelayanan, yaitu persyaratan teknis dan administrative yang diperlukan untuk mendapatkan pelayanan sesuai dengan jenis pelayanannya.

3. Kejelasan tugas pelayanan, yaitu keberadaan dan kepastian petugas yang memberikan pelayanan (nama, jabatan, serta kewenangan dan tanggung jawab).

4. Kedisiplinan petugas pelayanan, yaitu kesungguhan petugas dalam memberikan pelayanan terutama terhadap konsistensi waktu kerja sesuai dengan ketentuan yang berlaku.

5. Tanggung jawab petugas pelayanan, yaitu kejelasan wewenang dan tanggung jawab petugas dalam penyelenggaraan pelayanan.

\footnotetext{
${ }^{10}$ Kurniawan, 2006, Manajemen Pelayanan Umum, Jakarta : Bumi Aksara, hlm. 275.

${ }^{11}$ Sinambela, Lijan Poltak, 2010, Reformasi Layanan Publik, Jakarta : PT. Bumi Aksara, hlm. 3.
} 
6. Kemampuan petugas pelayanan, yaitu tingkat keahlian dan keterampilan yang dimiliki petugas dalam memberikan/menyelesaikan pelayanan kepada masyarakat.

7. Kecepatan pelayanan, yaitu target pelayanan dapat diselesaikan sesuai dengan waktu yang telah ditentukan.

8. Keadilan mendapatkan pelayanan, yaitu pelaksanaan pelayanan dengan tidak membedakan golongan/status masyarakat yang dilayani.

9. Kesopanan dan keramahan petugas, yaitu keterjangkauan masyarakat terhadap pembiayaan yang ditetapkan oleh unit pelayanan.

10. Kewajaran biaya pelayanan, yaitu keterjangkauan masyarakat terhadap pembiayaan yang ditetapkan oleh unit pelayanan.

11. Kepastian biaya pelayanan, yaitu kesesuaian antara biaya yang ditetapkan dengan biaya yang dibayarkan.

12. Kepastian jadwal/pelayanan, yaitu pelaksanaan waktu pelayanan sesuai dengan waktu yang ditetapkan.

13. Kenyamanan lingkungan, yaitu kondisi sarana dan prasarana pelayanan yang bersih, rapi dan teratur sehingga dapat memberikan rasa nyaman kepada penerima pelayanan.

14. Keamanan pelayanan, yaitu terjaminnya tinggkat keamanan lingkungan unit penyelenggara pelayanan ataupun sarana yang digunakan sehingga masyarakat merasa senang untuk mendapatkan pelayanan terhadap resiko-resiko yang akibatnya dari pelaksanaan.

Menurut UU No. 36 Tahun 2009 tentang Kesehatan, Pasal 54 dan Pasal 55. Sebagai acuan, Menkes RI telah mengeluarkan SPM Bidang Kesehatan No.43 Tahun 2016. Kementerian kesehatan juga telah sepakat menambahkan kriteria SPM kesehatan yaitu :

1. Merupakan pelayanan yang langsung dirasakan masyarakat, sehingga hal-hal yang berkaitan dengan manajemen dianggap sebagai faktor pendukung dalam melaksanakan urusan wajib (perencanaan, pembiayaan, pengorganisasian, perizinan, sumberdaya, sistem, dsb), tidak dimasukkan dalam SPM (kecuali critical support function).

2. Merupakan Prioritas tinggi bagi Pemerintah Daerah karena melindungi hak-hak konstitusional perorangan dan masyarakat, untuk melindungi kepentingan nasional dan memenuhi komitmen nasional dan global serta merupakan penyebab utama kematian/kesakitan.

3. Berorientasi pada output yang langsung dirasakan masyarakat.

4. Dilaksanakan secara terus menerus (sustainable), terukur (measurable), dan dapat dikerjakan (feasible). ${ }^{12}$

Untuk SPM rawat jalan, Menteri Kesehatan telah mengeluarkan Keputusan No.129/Menkes/SK/II/2008 Tentang Standar Pelayanan Minimal Rumah Sakit yang didalamnya telah ditetapkan mengenai indikator dan standar tiap pelayanan, salah satunya mengenai Rawat Jalan.

12 Kementrian Kesehatan RI, 2010, Rencana Strategis Kementrian Kesehatan Tahun 2010-2014, http://www.depkes.go.id, diakses pada tanggal 17 Mei 2018. 
Pembangunan di bidang kesehatan adalah tanggung jawab dari Pemerintah Pusat dan Pemerintah Daerah, karena pentingnya kebutuhan akan kesehatan dan perbedaan dari sumber daya dari tiap pemerintah daerah, maka dibuatlah standar dengan Standar Pelayanan Minimal (SPM). "Salah satu prinsipnya adalah SPM merupakan kewajiban bagi Pemerintah Daerah untuk menjamin setiap warga negara memperoleh kebutuhan dasarnya, " menurut dr. Untung Suseno Sutarjo, M.Kes. ${ }^{13}$

Mengembangkan nilai-nilai dasar dalam pelayanan kesehatan yaitu berpihak pada rakyat, bertindak cepat dan tepat, kerjasama tim, integritas yang tinggi, transparansi dan akuntabilitas dan semua ini membutuhkan kerjasama yang terpadu dari berbagai unsur. ${ }^{14}$

Salah satu sistem pembangunan kesehatan adalah kegiatan yang berorientasi melalui pelayanan kesehatan dasar. ${ }^{15}$

Otonomi daerah yang berorientasi pada tercapainya keadilan, pemberdayaan dan meningkatnya kesejahteraan serta pelayanan bagi masyarakat dengan salah satunya di bidang kesehatan, walaupun regulasi secara sektoral tetap dari pusat. ${ }^{16}$

Untuk memperkuat dan memperbaiki mutu pelayanan yang diberikan maka diadakanlah akreditasi yang diprakarsai oleh Depkes untuk membangun suatu mekanisme penilaian pada rumah sakit terhadap standar guna memastikan dipenuhinya standar tersebut. ${ }^{17}$

\section{Teori Perlindungan Hukum}

Satjipto Raharjo : "Perlindungan hukum adalah memberikan pengayoman kepada hak asasi manusia yang dirugikan oleh orang lain dan perlindungan tersebut diberikan kepada masyarakat agar mereka dapat menikmati semua hak-hak yang diberikan oleh hukum. “18

Philipus M. Hadjon : "Perlindungan hukum adalah perlindungan akan harkat dan martabat, serta pengakuan terhadap hak-hak asasi manusia yang dimiliki oleh subyek hukum berdasarkan ketentuan hukum dari kesewenangan." ${ }^{19}$

CST Kansil : "Perlindungan hukum adalah berbagai upaya hukum yang harus diberikan oleh aparat penegak hukum untuk memberikan rasa aman, baik secara pikiran maupun fisik dari gangguan dan berbagai ancaman dari pihak manapun."20

Muktie, A. Fadjar : "Perlindungan hukum adalah penyempitan arti dari perlindungan, dalam hal ini hanya perlindungan oleh hukum saja. Perlindungan yang diberikan oleh hukum, terkait pula dengan adanya hak dan kewajiban, dalam hal ini yang dimiliki oleh manusia sebagai subyek hukum dalam interaksinya dengan sesama manusia serta lingkungannya.

13 Kemenkes, Kemenkes Tekankan pentingnya SPM Bidang Kesehatan, http://www.depkes.go.id, diakses pada tanggal 20 Mei 2018.

${ }^{14}$ Hetty Ismaniar, 2015, Administrasi Kesehatan masyarakat, Yogyakarta : Deepublish, hlm. 11.

${ }^{15}$ Alexander Lucas Slamet Riyadi, 2016, Ilmu Kesehatan Masyarakat, Yogyakarta : Andi Offset, hlm. 254.

${ }^{16}$ Syamsuddin Haris, 2014, Masalah-Masalah Demokrasi Kebangsaan Era Reformasi, Jakarta : Yayasan Pustaka Obor Indonesia, hlm.199.

${ }^{17}$ A.F. Al-Assaf, 2009, Mutu Pelayanan Kesehatan: Perspektif Internasional, Jakarta : EGC, hlm. 214.

${ }^{18}$ Satjipto Rahardjo, 2010, Penegakan Hukum Progresif, Jakarta : PT Kompas Media Nusantara, hlm. 74.

${ }^{19}$ Philipus M. Hadjon, 2015, Perlindungan Hukum Bagi Rakyat Indonesia, Surabaya : Bina Ilmu, hlm. 25.

${ }^{20}$ CST Kansil, 2011, Pengantar Ilmu Hukum dan Tata Hukum Indonesia, Jakarta : Rineka Cipta, hlm. 102. 
Sebagai subyek hukum manusia memiliki hak dan kewajiban untuk melakukan suatu tindakan hukum." 21

Setiono: "Perlindungan hukum adalah tindakan atau upaya untuk melindungi masyarakat dari perbuatan sewenang-wenang oleh penguasa yang tidak sesuai dengan aturan hukum, untuk mewujudkan ketertiban dan ketentraman sehingga memungkinkan manusia untuk menikmati martabatnya sebagai manusia."22

Di dalam undang-undang ada jarak yang besar yang menyebabkan kesenjangan baik dalam tata bahasa dan kosakata, sehingga banyak mengandung keterbatasan dan dibutuhkan komponen penjelasan untuk mendapatkan kepastian hukum karena hukum tidak berjalan menurut logika saja dan tidak hanya berpegangan secara mutlak kepada teks formal suatu peraturan saja tapi harus dipertimbangkan unsur kemanfaatan sosial (reasonable) agar masyarakat mendapatkan perlindungan. ${ }^{23}$

Perlindungan hukum membutuhkan wadah dalam pelaksanaannya, yang dibagi menjadi 2 yaitu :

1. Sarana Perlindungan Hukum Preventif : Disini subyek hukum diberikan kesempatan untuk mengajukan keberatan atau pendapatnya sebelum suatu keputusan pemerintah mendapat bentuk yang definitif. Tujuannya adalah mencegah terjadinya sengketa.

2. Sarana Perlindungan Hukum Represif : Perlindungan hukum yang represif bertujuan untuk menyelesaikan sengketa. Penanganan perlindungan hukum oleh Pengadilan Umum dan Pengadilan Administrasi di Indonesia termasuk kategori perlindungan hukum ini. $^{24}$

\section{Teori hak.}

Sudikno Metrokusumo : Hak adalah kepentingan yang dilindungi oleh hukum. Hak mengandung empat unsur yang saling berhubungan, yaitu : Subjek hukum, Objek hukum, Hubungan hukum yang mengikat pihak lain dengan kewajiban, dan Perlindungan hukum.

Satjipto Rahardjo : Hak adalah kekuasaan yang diberikan oleh hukum kepada seseorang, dengan maksud untuk melindungi kepentingan seseorang tersebut. ${ }^{25}$

Thomas Aquinas : hak adalah "Keseimbangan yang secara kodrat melekat di dalam semua hal, atau sesuatu yang diberikan kepada orang lain sebagai pesona berdasarkan asas persamaan derajat. Konsep ini berkaitan denga sila kelima dari Pancasila, keadilan sosial bagi seluruh rakyat Indonesia dimana didalam sila ini diaktualisasikan hak-hak dasar manusia dimana manusia memiliki hak atas dasar hakikatnya menurut perintah illahi, diluar kewenangannya dan hak atas dasar kegunaannya berdasarkan atas dasar akal budi dan kehendak sesuai karena ia mampu menggunakannya." 26

\footnotetext{
${ }^{21}$ A. Muktie Fadjar, 2005, Tipe Negara Hukum, Malang : Bayumedia Publishing, hlm. 40-41.

22 Setiono, 2004, Rule of Law (Supremasi Hukum), Surakarta, Magister Ilmu Hukum Pascasarjana Universitas sebelas Maret, hlm.3.

23 Satjipto Rahardjo, op. cit, hlm. 66.

24 Philipus M. Hadjon, op. cit, hlm. 30.

25 Satjipto Rahardjo, 1996, Ilmu Hukum, Bandung : Citra Aditya Bakti, hlm. 94.

${ }^{26}$ E. Sumaryono, 2006, Etika Hukum Relevansi Teori Hukum Kodrat Thomas Aquinas, Yogyakarta : Kanisius, hlm. 260.
} 
Van Apeldoorn : "Hak adalah sebuah kekuatan (macht) yang diatur oleh hukum, dan kekuasaan ini berdasarkan kesusilaan (moral) dan tidak hanya kekuatan fisik saja. Hak ialah hukum yang dihubungkan dengan seorang manusia atau subjek hukum tertentu. Dengan demikian, kekuatan menjelma menjadi kekuasaan hingga akhirnya suatu hak timbul apabila mulai bergerak."

Lemaire "Hak adalah suatu dengan izin. Izin yang bersangkutan untuk berbuat sesuatu. Akan tetapi izin ini bukan bersumber pada hukum, melainkan sejajar atau sederajat dengan hukum. Hukum berupa perintah/larangan atau izin. Hak adalah hukum yang berupa izin."27

Pasal 2 Undang-Undang No.29 Tahun 2004 Tentang Praktik Kedokteran, menjelaskan bahwa : Penyelenggaraan Praktik Kedokteran dilaksanakan berasaskan Pancasila dan didasarkan pada nilai ilmiah, manfaat, keadilan, kemanusiaan, keseimbangan, serta perlindungan dan keselamatan pasien.

Pasal 3 Undang-Undang No.29 Tahun 2004 Tentang Praktek Kedokteran, dikatakan bahwa Praktik Kedokteran bertujuan :

Pasal 52-53 Undang-Undang No.29 Tahun 2004 Tentang Praktik Kedokteran. ${ }^{28}$

Seorang dokter dalam melayani pasien harus senantiasa menjunjung tinggi nilai-nilai kemanusiaan dan berusaha semaksimal mungkin berlaku adil dan tidak melupakan nilai-nilai sosial dimasyarakat. ${ }^{29}$

Setiap pasien berhak menerima atau menolak sebagian atau seluruh tindakan pertolongan yang akan diberikan kepadanya setelah menerima dan memahami informasi mengenai tindakan tersebut secara lengkap, sesuai Pasal 56 Undang-Undang No.36 Tahun 2009 Tentang Kesehatan.

Sebaliknya apa yang menjadi kewajiban pasien adalah menjadi hak dan kewajiban dokter seperti yang tercantum dalam Pasal 50-51 Undang-Undang No. 29 Tahun 2004 Tentang Praktik Kedokteran.

Pelayanan kesehatan ini harus berdasarkan asas manfaat yaitu memberikan manfaat yang sebesar-besarnya bagi kemanusiaan dan perikehidupan yang sehat bagi warga negara dan asas keadilan yaitu terjangkau oleh semua warga masyarakat, semua warga harus mempunyai akses dalam pelayanan kesehatan yang layak. ${ }^{30}$

Dalam melakukan pekerjaan/tindakan medis penilaiannya adalah bila sekelompok tenaga kesehatan akan melakukan ketelitian yang sama dalam situasi dan kondisi yang sama, maka ukuran ketelitian itu yang diambil. ${ }^{31}$

Hubungan antara dokter dengan pasien sebagai penerima pelayanan kesehatan, berada dalam ikatan transaksi terapeutik (inspanningsverbintenis yaitu perjanjian upaya artinya kedua belah pihak yang berjanji berdaya upaya secara maksimal untuk mewujudkan apa yang diperjanjikan). Ini termasuk dalam ikatan ikhtiar, kewajiban hukum atau prestasi yang

${ }^{27}$ R. Soeroso, 2017, Pengantar llmu Hukum, Jakarta : Sinar Grafika, hlm. 274.

${ }^{28}$ Muhamad Sadi Is, 2015, Etika Hukum Kesehatan, Jakarta: Prenada Media, hlm. 92-94.

${ }^{29}$ H. Muntaha, 2017, Hukum Pidana Malapraktik Pertanggungjawaban dan Penghapus Pidana, Jakarta : Sinar Grafika, hlm. 55-56.

${ }^{30}$ M. Jusuf Hanafiah, Amri Amir, 2008, Etika Kedokteran Dan Hukum Kesehatan, Jakarta: EGC, hlm. 3031.

${ }^{31}$ Wila Chandrawila Supriadi, 2001, Hukum Kedokteran, Bandung : Mandar Maju, hlm. 52-53. 
harus diwujudkan oleh dokter adalah ikhtiar semaksimal mungkin dalam batas keahliannya untuk menyembuhkan pasien. Dikatakan sebagai wanprestasi atau ingkar janji jika dokter tidak melakukan prestasi sesuai dengan apa yang seharusnya disepakati. Dikatakan melakukan perbuatan melawan hukum jika terapi yang dilakukan oleh dokter menyimpang dari patokan atau standar yang ditentukan. ${ }^{32}$

\section{Kedudukan dalam hukum}

Kedudukan dalam hukum bagi setiap manusia adalah sama. Persamaan kedudukan manusia di hadapan hukum adalah salah satu hak manusia yang harus diakui.

Menurut Thomas Aquinas : "Kedudukan manusia di dalam hukum didasarkan atas konsep hukum, moralitas, dan keadilan yang saling berhubungan dan memberikan solusi."

Berdasarkan filsafat hukum, kedudukan manusia di mata hukum adalah makhluk yang otonom dan unik memiliki kebebasan yang diperoleh berdasarkan keberadaannya sebagai makhluk rasional dan manusia adalah persona yang korelatif. ${ }^{33}$

Dalam pelayanan kesehatan, tenaga kesehatan dalam bekerja harus berdasarkan indikasi medik dan tidak bersikap diskriminasi terhadap pasien yang dilayani, tanpa memandang mampu atau tidak mampu, berpangkat atau tidak berpangkat, suku, agama dan golongan tertentu, semua dilakukan demi kepentingan terbaik bagi seorang pasien dan diutamakan bagi keselamatan dan kesembuhan pasien. ${ }^{34}$

Pasien berhak menerima pelayanan kesehatan dari tenaga kesehatan terbaik dalam promotif, preventif, kuratif maupun rehabilitatif. Pasien harus mengikuti semua anjuran baik dalam pengobatan maupun pemeriksaan anjuran lainnya dari tenaga kesehatan seperti pemeriksaan laboratorium dan pemeriksaan pencitraaan lain sebagai penunjang dalam menegakkan diagnosa yang lebih akurat dan dapat dipertanggungjawabkan. ${ }^{35}$

Sebagai seorang profesional dalam pelayanan kepada pasien seorang dokter harus mempunyai perilaku yang profesional dengan memperhatikan budi pekerti luhur manusia dan mengedepankan budi pekerti sesuai Pancasila. ${ }^{36}$ Profesionalitas merupakan kualitas sikap para anggota suatu profesi terhadap profesinya serta derajat pengetahuan dan keahlian yang mereka miliki untuk dapat melakukan tugas-tugasnya. ${ }^{37}$ Seorang profesional juga mengutamakan keahlian yang berlandaskan kode etik dan ketentuan peraturan perundang-undangan yang berlaku. ${ }^{38}$

\footnotetext{
${ }^{32}$ Bahder Johan Nasution, 2013, Hukum Kesehatan Pertanggungjawaban Dokter, Jakarta: Rineka Cipta, hlm. 23-34.

33 Thomas Aquinas, op. Cit., hlm. 251.

34 Rachmat Alyakin Dachi, 2017, Proses dan Analisis Kebijakan Kesehatan, Yogyakarta : Deepublish, hlm. 1.

35 Sri Siswati, 2015, Etika dan Hukum Kesehatan Dalam Perspektif Undang-Undang Kesehatan, Jakarta : PT Raja Grafindo Persada, hlm. 52-55.

${ }^{36}$ Satjipto Rahardjo, 2009, Hukum dan Perilaku, Jakarta : Kompas, hlm. 104.

${ }^{37}$ Silviani Kesuma, 2015, The Ability Diagnostic Reading for Change, Yogyakarta : Deepublish, Yogyakarta, hlm. 73.

${ }^{38}$ Ahmad Qodri Abdillah Azizy, 2007, Change Management Dalam Reformasi Birokrasi, Jakarta : Gramedia, hlm. 50.
} 


\section{Kewenangan}

Prajudi Atmosudirjo : "Kewenangan adalah apa yang disebut kekuasaan formal, kekuasaan yang berasal dari kekuasaan legislatif (diberi oleh Undang-Undang) atau dari kekuasaan eksekutif/administratif." 39

Indroharto : "wewnang diperoleh secara atribusi, delegasi, dan mandat"

Philipus M. Hadjon : "Wewenang dideskripsikan sebagai kekuasaan hukum, jadi wewenang berkaitan dengan kekuasaan."40

F. P. C. L. Tonnaer : "Kewenangan pemerintah dianggap sebagai kemampuan untuk melaksanakan hukum positif, dirincikan dalam hubungan hukum antara pemerintah dan warga negara."

H. D Stout : "Wewenang dijelaskan sebagai keseluruhan aturan-aturan yang berkenaan dengan perolehan dan penggunaan wewenang pemerintahan oleh subjek hukum publik di dalam hubungan hukum publik." ${ }^{41}$

S. F. Marbun : "Wewenang adalah kemampuan untuk melakukan suatu tindakan hukum publik atau secara yuridis adalah kemampuan bertindak yang diberikan oleh undangundang yang berlaku untuk melakukan hubungan-hubungan hukum." ${ }^{42}$

Aspek kewenangan cirinya ada 2 yaitu : Atributif dan non atributif.

Pelimpahan wewenang ada 2 : Delegasi dan mandat.

Kewenangan Propinsi sebagai Daerah Otonom, hanya diperkenankan menyelenggarakan kegiatan otonomi sebatas yang ditetapkan dalam Peraturan Pemerintah. ${ }^{43}$

\section{Pelayanan Rawat Jalan}

Asrul Azwar : Pelayanan medis kepada seorang pasien untuk tujuan pengamatan, pengobatan, rehabilitasi, dan pelayanan kesehatan lainnya, tanpa mengharuskan pasien tersebut dirawat inap (opname). Secara sederhana dimaksudkan yaitu pelayanan kedokteran yang disediakan untuk pasien tidak dalam bentuk rawat inap. ${ }^{44}$

Pelayanan rawat jalan di rumah sakit ada 4 macam, yaitu : Pelayanan gawat darurat, Pelayanan rawat jalan, Pelayanan, Pelayanan bedah jalan

\footnotetext{
39Prajudi Atmosudirdjo, 1994, Hukum administrasi Negara, Jakarta : Ghalia Indonesia, hlm. 382.

${ }^{40}$ Philipus M. Hadjon, 2018, Administrasi Negara, Jakarta : Chalia Indonesia, hlm. 90.

${ }^{41}$ Ridwan H. R, 2013, Hukum Administrasi Negara, Cet. Ke-8, Jakarta : Rajawali Pers, hlm. 100.

${ }^{42}$ S. F, Marbun, 2011, Peradilan Administrasi Negara dan Upaya Administratif di Indonesia, Yogyakarta: FH UII Press, hlm. 198

43 Deddy Supriady, op. Cit., hlm. 34.

${ }^{44}$ Azrul Azwar, 1996, Menuju Pelayanan Kesehatan Yang Lebih Bermutu, Jakarta : Yayasan Penerbitan Ikatan Dokter Indonesia, hlm. 168.
} 


\section{PEMBAHASAN}

\section{Pengaturan Standar Pelayanan Minimal Rawat Jalan di Kabupaten Bogor}

Dari penelitian yang dilakukan di Dinas Kesehatan Kabupaten Bogor, berdasarkan hasil wawancara dengan dr. Dedi Syarif, MA, selaku Kepala Seksi Yankesruj (Pelayanan Kesehatan dan Rujukan), yang mewakili Kepala Dinas Kesehatan Kabupaten Bogor, dikatakan:

"Di Kabupaten Bogor tidak ada peraturan daerah yang mengatur mengenai Standar Pelayanan Minimal bidang Kesehatan, yang ada hanya Renstra Dinas Kesehatan Tahun 2013-2018 yang dijadikan sebagai landasan/pedoman dalam penyusunan Renja Dinas Kesehatan, penguatan peran para stakeholders dalam pelaksanaan Perencanaan Pembangunan Daerah, serta sebagai dasar evaluasi dan laporan pelaksanaan atas kinerja tahunan dan lima tahunan Dinkes Kabupaten Bogor.

Di Kabupaten Bogor tidak memiliki Standar Pelayanan Minimal Bidang Kesehatan. Dinas Kesehatan Kabupaten Bogor sebagai acuan Standar Pelayanan Minimal dan masih mengacu pada Peraturan Menteri Kesehatan No. 56 Tahun 2014 tentang Klasifikasi dan Perizinan Rumah Sakit, dan Renstra Dinas Kesehatan Tahun 2013-2018 masih mengacu berdasarkan Permenkes No. 741/Menkes/PER/VII/2008 tentang Standar Pelayanan Minimal Bidang Kesehatan Di Kabupaten/Kota.“

Dinas Kesehatan Kabupaten Bogor menurut dr. Dedi Syarif, MA, telah menjalankan fungsi sebagai regulasi dan sebagai pengawas dari 28 rumah sakit, meliputi Rumah Sakit Swasta dan Rumah Sakit Pemerintah/Rumah Sakit Umum Daerah (RSUD), yang berada di Kabupaten Bogor. Dinas kesehatan berfungsi membantu mengatasi setiap permasalahan yang mungkin timbul di tiap rumah sakit dengan melakukan pendekatan ke rumah sakit tersebut. Pendekatan ini dilakukan Upaya Dinas Kesehatan agar mencegah timbulnya permasalahan di rumah sakit yaitu dengan mengadakan pembinaan yang diadakan tiap 2 atau 3 bulan sekali dan diadakannya pertemuan rutin tiap setahun sekali yang dilakukan di Dinas Kesehatan Kabupaten Bogor. Diutamakan tiap permasalahan dilakukan penyelesaian dengan cara mediasi terlebih dahulu dan diharapkan tidak sampai ke meja pengadilan. Cara penyelesaiannya itu sendiri, jika ada masalah pada rumah sakit diutamakan dengan cara mediasi. Sanksi bagi rumah sakit jika melakukan kesalahan maka akan diberikan sanksi administratif yaitu pemberian peringatan kesatu, lalu pemberian peringatan kedua, dan akhirnya jika sudah mendapatkan teguran ketiga maka akan diberikan teguran pada rumah sakit tersebut dari Dinkes Kabupaten Bogor."45

Dari hasil wawancara di Rumah Sakit Mary, Cileungsi Hijau, dengan Bagian Pelayanan Medik dr. Andrawina sebagai perwakilan dari Direktur Rumah Sakit Mary, Cileungsi Hijau, dengan tegas dikatakan bahwa :

"Jika SPM Rawat Jalan yang diterapkan di Rumah Sakit Mary sudah terlaksana sesuai standar yang berlaku didaerah Bogor yaitu standar Rumah Sakit Tipe C. Standar ini digunakan sejak lama seperti yang telah ditetapkan Dinas Kesehatan Kabupaten Bogor. Seperti yang dikatakan oleh dr. Andrawina jika SPM Rawat Jalan sesuai Permenkes No. 43 Tahun 2016 Tentang Standar Pelayanan Minimal Bidang Kesehatan, beliau sudah

${ }^{45}$ Dedi Syarif, Kepala Seksi Yankesruj Dinas Kesehatan Kabupaten Bogor, Wawancara Tanggal 17 April 2018. 
mengetahui namun dikatakan tidak menjadi acuan karena Rumah Sakit Mary, Cileungsi Hijau adalah rumah sakit ber tipe C. SPM ini pun dijadikan patokan saat rumah sakit menjalani akreditasi. Namun walaupun demikian, dalam struktur rumah sakit untuk aturan-aturan didalam rumah sakit tetap dilakukan aturan yang baku seperti yang ada dalam Permenkes No. 43 Tahun 2016."46

Pada Rumah Sakit Mary, Cileungsi Hijau SPM yang dipakai belum mengacu kepada Permenkes No. 43 tahun 2016 tentang Standar Pelayanan Minimal di Bidang Kesehatan, namun masih mengacu kepada SPM yang sesuai dengan Permenkes No. 56 Tahun 2014 Tentang Klasifikasi dan Perizinan Rumah Sakit.

Dari hasil wawancara dengan dr. Lugina Jatianita selaku Manager Pemasaran, Humas Ketua Komite Mutu dan Keselamatan Pasien yang mewakili direktur Rumah Sakit Sentosa, Parung, dikatakan bahwa : "Permenkes yang dijadikan sebagai patokan untuk SPM Rawat jalan oleh Rumah Sakit Sentosa sejak dilakukan akreditasi hingga sekarang, yaitu Permenkes Nomor 43 Tahun 2016 Tentang Standar Pelayanan Minimal Bidang Kesehatan. Dikatakan juga peranan dari Dinkes dikatakan nyaris tidak ada, namun rumah sakit berjalan sendiri mencari info terbaru sebagai acuan Rumah Sakit yaitu dari Permenkes No. 43 Tahun 2016 tentang Standar Pelayanan Minimal Bidang Kesehatan." 47

Pada RS Sentosa, Parung, SPM yang dipergunakan sudah mengacu kepada Permenkes No.43 Tahun 2016 tentang Standar Pelayanan Minimal Bidang Kesehatan, seperti yang telah dijadikan patokan terbaru dari Pemerintah.

SPM Bidang Kesehatan adalah tolok ukur kinerja pelayanan kesehatan yang diselenggarakan Daerah Kabupaten/Kota. Dalam penerapannya SPM Kesehatan harus memberikan jaminan kepada masyarakat dalam mendapatkan pelayanan dasar dari pemerintah daerah sesuai dengan ketentuan yang telah ditetapkan oleh Pemerintah. Tujuan dari pelayanan rawat jalan adalah mengupayakan kesembuhan dan pemulihan pasien secara optimal melalui prosedur dan tindakan yang dapat dipertanggungjawabkan (Standar Pelayanan Rumah Sakit, Dirjen Yanmed Depkes RI Tahun 1999). ${ }^{48}$

Pengaturan rumah sakit pada Permenkes No. 43 Tahun 2016 tentang Standar Pelayanan Minimal Bidang Kesehatan, mengatur tentang menyelenggarakan pelayanan dasar kesehatan sesuai SPM Bidang Kesehatan, dan pada Permenkes No. 129 Tahun 2008 tentang Standar Pelayanan Minimal Rumah Sakit, disini diatur mengenai SPM Rawat Jalan. Kedua Permenkes ini pengaturannya terhadap rumah sakit saling melengkapi, agar pelayanan yang didapat oleh pasien dapat dipenuhi secara maksimal, sesuai teori perlindungan hukum dari Satjipto Rahardjo. Pelayanan kesehatan ini harus berdasarkan asas dan keadilanProduk hukum atau peraturan internal di rumah sakit saat penelitian tidak diberikan, sehingga peneliti hanya menganalisis berdasarkan hasil wawancara. Namun demikian, rumah sakit pengaturannya harus tetap tunduk pada peraturan yang

${ }^{46}$ Andrawina, Pelayanan Medik Rumah sakit Umum Mary, Cileungsi Hijau, Wawancara Tanggal 11 Mei 2018.

47 Lugina Jatianita, Manager Pemasaran, Humas Ketua Komite Mutu dan Keselamatan Pasien, Rumah Sakit Sentosa, Parung, Wawancara Tanggal 14 Mei 2018.

${ }^{48}$ Dinas Kesehatan Kabupaten Bogor, 2013-2018, Renstra Dinas Kesehatan 2013-2018 Pemerintah kabupaten Bogor, http://www.bogorkab.go.id, diakses pada tanggal, 17 Mei 2018. 
diterbitkan Pemerintah sesuai Permenkes No. 43 tahun 2016 dan Permenkes No. 56 Tahun 2014.

Bagi Dinas Kesehatan Kabupaten Bogor, tidak ada Perda Standar Pelayanan Minimal, tetapi ada beberapa produk hukum yang mengatur tentang Bidang Kesehatan, yang menjadi dasar hukum dari pelaksanaan standar pelayanan minimal ada pada : Renstra Dinas Kesehatan Tahun 2013-2018, Permenkes No. 56 Tahun 2014 tentang Kalisifikasi dan Perizinan Rumah Sakit, Perda No. 5 Tahun 2014 tentang RJPMD yang diubah dengan Perda No. 4 Tahun 2017 yang mengatur Bidang Kesehatan, Perda No. 9 Tahun 2015 tentang HIV/AIDS, dan Pasal 2 huruf d angka 4 Perda No. 12 Tahun 2016 tentang Pembentukan dan Susunan Perangkat Daerah, "Yang mengatur Dinkes Tipe A menyelenggarakan urusan pemerintahan bidang kesehatan." Peraturan-peraturan tersebut memberi kewenangan pada Pemda dan Dinkes Kabupaten Bogor untuk mengatur Standar Pelayanan Minimal, sesuai aturan yang berlaku.

Dinkes Bogor masih mengacu kepada Permenkes No. 56 Tahun 2014 tentang Klasifikasi dan Perizinan RS dalam pengaturan SPM. Demikian pula rumah sakit yang bernaung di bawah Dinkes. Dapat dilihat dari hasil wawancara dengan perwakilan dari Direktur RS Mary, Cileungsi Hijau, dimana rumah sakit tersebut masih menggunakan SPM sesuai dengan klasifikasi rumah sakitnya yang masuk dalam rumah sakit type C. RS Sentosa, Parung, dengan inisiatif sendiri, pelaksana rumah sakit tersebut mengerti akan adanya Permenkes terbaru yang mengatur mengenai SPM maka mereka langsung menerapkan apa yang telah ditetapkan dan menjadi kebijakan yang harus dilakukan meski aturan di Dinkes Bogor masih mengacu ke aturan yang lama. Maka dengan adanya SPM yang telah dikeluarkan oleh Menkes seharusnya peraturan itu telah berjalan sejak ditetapkan.

2. Faktor-faktor apa saja yang mempengaruhi pelaksanaan Standar Pelayanan Minimal Rawat Jalan di Kabupaten Bogor

Upaya Dinas Kesehatan agar mencegah terjadinya masalah di rumah sakit dengan mengadakan pembinaan yang diadakan tiap 2 atau 3 bulan sekali oleh Dinas Kesehatan Kabupaten Bogor. Dilakukan juga pertemuan rutin tiap setahun sekali dengan mengumpulkan pimpinan Rumah Sakit yang dilakukan di Dinas Kesehatan Kabupaten Bogor. SPM di Rumah Sakit Mary, Cileungsi Hijau, belum mengacu ke Permenkes No. 43 Tahun 2016 namun masih mengikuti standar Rumah Sakit Tipe C. Jika terjadi masalah dalam pelayanan, penyelesaian akhir ditangani oleh pihak rumah sakit dengan bertemu dengan pihak keluarga pasien lewat proses mediasi. SPM di Rumah Sakit Sentosa, Parung, dapat dilakukan dengan baik berkat pimpinan yang giat mencari informasi dan memberikan semangat dalam bekerja dengan cara ikut serta dalam memberikan pelayanan, untuk komitmen bersama dalam memberikan pelayanan yang terbaik bagi pasien.

Menurut Dinas Kesehatan Kabupaten Bogor, dr. Dedi Syarif, MA, dikatakan : Alasan utama sulitnya diterapkan Permenkes No. 43 tahun 2016 tentang Standar Pelayanan Minimal di Bidang Kesehatan, adalah oleh karena masing-masing Rumah Sakit di Kabupaten Bogor mempunyai kebijakan masing-masing dari rumah sakitnya sendiri dan ini ditentukan oleh manajemen dan organisasi rumah sakit. Dikatakan juga karena tidak adanya SPM dari Pemerintah Daerah maka yang menjadi acuan adalah Renstra Dinas Kesehatan Tahun 2013-2018 masih mengacu berdasarkan Permenkes No. 741/Menkes/PER/VII/2008 tentang Standar Pelayanan Minimal Bidang Kesehatan Di Kabupaten/Kota. 
Rumah Sakit Mary, Cileungsi Hijau, mengatakan : Karena terbatasnya kapasitas tempat tidur yang dimiliki oleh rumah sakit, dianggap tidak tanggap oleh pasien dalam hal pelayanan, sehingga kadang ada pasien yang tidak sabar karena merasa tidak dilayani dengan baik dan ini menimbulkan emosi pada pasien. Rumah Sakit Sentosa, Parung, mengatakan : Masalah waktu tunggu karena banyaknya spesialis, dengan kondisi ada satu dokter yang terlambat sehingga pasien harus menunggu sebentar akan berimbas ke bagian yang lain. Meski secara aturan normal tidak lebih dari 60 menit, pada kenyataan agak sulit menepati waktu yang 60 menit ini. Adanya kotak suara dan pengaduan lewat email untuk keluhan pasien di tiap Rumah Sakit sebagai fasilitas yang mendukung untuk melakukan perbaikan bagi Rumah Sakit dalam memberikan pelayanan kepada pasien.

\section{Pelaksanaan Standar Pelayanan Minimal Rawat Jalan di Kabupaten Bogor}

Pada Dinas Kesehatan Bogor dikatakan bahwa : "Dengan demikian pada saat sekarang Dinas Kesehatan Kabupaten Bogor dalam menerapkan SPM berpatokan pada Peraturan Menteri Kesehatan No. 56 Tahun 2014 tentang Klasifikasi dan Perizinan Rumah Sakit. Peraturan Menteri Kesehatan No. 43 tahun 2016 tentang Standar Pelayanan Minimal Bidang Kesehatan belum dijadikan patokan. Dalam pelaksanaan mengenai SPM Rawat jalan di rumah sakit, menurut dr. Dedi Syarif, MA dalam tahun-tahun terakhir ini rumah sakit di Kabupaten Bogor dinyatakan dalam keadaan baik dan tidak mendapatkan masalah yang berarti dalam pelayanan, yang berarti masih memenuhi standar pelayanan yang dijadikan patokan. SPM di Kabupaten Bogor dianggap sudah paripurna dilihat dari indikator Akreditasi tiap rumah sakit yang sudah memenuhi syarat".

Berdasarkan hasil wawancara dengan dr. Lucky Novianti: dokter rawat jalan di unit IGD Rumah Sakit Mary, Cileungsi Hijau, dikatakan bahwa : "Penanganan pasien sudah dilakukan sesuai SPM Rawat Jalan yang berlaku. Dalam hal ini rumah sakit telah berupaya untuk menambah tempat tidur dalam upaya menambah kapasitas pelayanan. Jika ada pasien yang merasa tidak puas dengan pelayanan rawat jalan dapat memberikan saran lewat kotak suara meski tidak jarang ada pula pasien yang langsung mengeluarkan emosinya. Jika hal ini terjadi maka pasien langsung mendatangi pihak staf rumah sakit untuk melakukan protes nya. Dan biasanya penyelesaian akhir ditangani oleh pihak rumah sakit dengan pihak keluarga pasien."49

Dalam wawancara dengan dr. Lugina Jatianita, bahwa : "Di Rumah Sakit Sentosa, Parung, yang mempunyai motto rumah sakit "Kepuasan dan Kenyamanan pasien adalah prioritas kebahagiaan kami”, dalam pelayanan selalu mengutamakan pasien, sehingga pasien merasakan mendapatkan kenyamanan, kepuasan dalam pelayanan dan perlindungan dari rumah sakit. Ini diwujudkan dengan membantu dalam pelayanan pasien semaksimal mungkin dari awal hingga pasien dinyatakan sembuh atau dirujuk. Dalam pelaksanaannya nilai patokan bisa naik turun, namun masih dalam batas normal. Ini disebabkan karena terbatasnya kapasitas tempat tidur yang dimiliki, ini dianggap tidak tanggap oleh pasien sehingga ada pasien yang tidak sabar karena merasa tidak dilayani dengan baik. Dalam hal masalah kepuasan pasien, menurut dr. Pujiastuti sebagai Manager Pelayanan Medis, Komite Mutu dan Pelayanan Pasien, Rumah Sakit Sentosa, ada pasien yang melakukan complain secara langsung ada juga yang tidak langsung. Jika complain langsung, akan ditampung terlebih dahulu oleh pihak rumah

49 Lucky Novianti, dokter Rawat Jalan IGD Rumah Sakit Umum Mary, Cileungsi Hijau, Wawancara Tanggal 11 Mei 2018. 
sakit. Untuk complain yang tidak langsung, diberikan format tentang complain untuk pengaduan pasien. Untuk penanganan, dari pimpinan rumah sakit ada pendekatan ke dokter yang dicomplain dengan penyelesaian lewat pendekatan kekeluargaan dan tahapan ini diselesaikan lewat komite medik." 50

Pada pelaksanaannya, SPM yang diatur pada Permenkes No. 43 Tahun 2016 sudah terpenuhi meski masih ada rumah sakit yang belum menjadikan acuan dalam bekerja. Sesuai dengan Undang-Undang No. 23 Tahun 2014 tentang Pemerintahan Daerah, Pasal 18 ayat (1) yaitu : "Pelaksanaan Pelayanan Dasar pada Urusan Pemerintahan Wajib yang berkaitan dengan Pelayanan Dasar sebagaimana dimaksud pada ayat (1) berpedoman pada standar pelayanan minimal yang ditetapkan oleh Pemerintah Pusat." Menurut sumber wawancara, SPM Rawat Jalan di RS telah sesuai dengan Permenkes No. 56 Tahun 2014 tentang Klasifikasi dan Perijinan Rumah Sakit. Rumah Sakit yang dilakukan penelitian adalah rumah sakit dengan tipe $C$, dan rumah sakit tersebut sudah sesuai dengan kriteria rumah sakit tipe $C$. Namun yang masih menjadi kendala bagi tiap rumah sakit, yaitu kurangnya sumber daya manusia dan tempat tidur pasien di ruang IGD. Sehingga dalam hal pelayanan dianggap kurang tanggap dan bermasalah dalam hal waktu tunggu. Dari hasil wawancara yang didapat, karena menumpuknya pasien yang ada di rawat jalan sering pasien menganggap jika mereka tidak dilayani dengan cepat. Dalam hal waktu tunggu, kondisi jalan daerah Bogor yang padat dan banyaknya jumlah pasien tidak bisa dipastikan akan sesuai seperti yang diharapkan oleh pasien, juga kondisi pasien yang gawat yang harus senantiasa didahulukan oleh petugas kesehatan membuat waktu tunggu hampir tidak bisa dipastikan sesuai seperti Standar Pelayanan Minimal yang telah ditetapkan. Satu hal yang membuat waktu tunggu selalu jadi panjang karena adanya faktor kepercayaan pasien yang tinggi pada dokter tertentu membuat daftar antrian panjang sehingga waktu tunggu menjadi lebih lama. Dengan demikian, pelaksanaan SPM rawat jalan di rumah sakit Kabupaten Bogor dapat dikatakan sudah memenuhi standar sesuai teori perlindungan hukum yang dikemukakan oleh Setiono, yaitu :"Perlindungan hukum adalah tindakan atau upaya untuk melindungi masyarakat dari perbuatan sewenang-wenang oleh penguasa yang tidak sesuai dengan aturan hukum, untuk mewujudkan ketertiban dan ketentraman sehingga memungkinkan manusia untuk menikmati martabatnya sebagai manusia."

Permenkes No. 43 Tahun 2016 tentang Standar Pelayanan Minimal Bidang Kesehatan, yang telah ditetapkan seharusnya telah dijadikan acuan dalam bekerja, agar pelayanan yang didapat oleh pasien sebagai manusia yang sama kedudukannya di dalam hukum sebagai perwujudan dari aspek keadilan dan kemanfaatan dapat terpenuhi. SPM Bidang Kesehatan dikaitkan dengan perlindungan hukum pada pasien rawat jalan, Satjipto Rahardjo berpendapat: "Perlindungan hukum adalah memberikan pengayoman kepada hak asasi manusia yang dirugikan oleh orang lain dan perlindungan tersebut diberikan kepada masyarakat agar mereka dapat menikmati semua hak-hak yang diberikan oleh hukum." Seperti di sarana perlindungan hukum preventif, Dinas Kesehatan Kabupaten Bogor, sebagai pusat dalam pelaksanaan Standar Pelayanan Minimal, yang berhubungan dengan perlindungan pasien menjadi tempat bagi penyelesaian jika ada masalah yang berkaitan antara pasien dan Rumah sakit. Di tiap rumah sakit juga diadakan kotak suara untuk pengaduan pasien, dan pengaduan online lewat nomor

\footnotetext{
50 Pujiastuti, dr, Manager Pelayanan Medis dan Komite Mutu dan Keselamatan Pasien, RS Sentosa, Parung, Wawancara Tanggal 14 Mei 2018.
} 
pengaduan dan email rumah sakit. Jika ada kasus protes mengenai pelayanan kepimpinan Rumah Sakit, maka dari pimpinan rumah sakit yang akan langsung mengambil alih seperti yang dilakukan di Rumah sakit Mary, Cileungsi Hijau. Dan di Rumah Sakit Sentosa, Parung, dilakukan juga penyelesaian secara kekeluargaan dari pihak pimpinan Rumah Sakit ke dokter pelaksana dan ke pasien, dimana penyelesaian disini diharapkan tidak menimbulkan sengketa yang berlarut-larut.

\section{KESIMPULAN}

Berdasarkan hasil pembahasan, maka dapatlah diambil kesimpulan sbb :

1. Pengaturan SPM Rawat Jalan di Kabupaten Bogor, seharusnya sudah mengikuti Permenkes No. 43 Tahun 2016 tentang Standar Pelayanan Minimal Bidang Kesehatan seperti yang telah ditetapkan oleh Menkes. Undang-Undang Nomor 23 tahun 2014 Tentang Pemerintahan Daerah telah menetapkan bahwa bidang Kesehatan adalah urusan wajib yang harus dilaksanakan oleh Kab/kota. Dengan adanya pengaturan tersebut diharapkan akan adanya perbaikan dalam pelayanan kepada masyarakat pada berbagai lapisan.

Kab. Bogor seharusnya membentuk Peraturan Daerah (Perda) tentang SPM Bidang Kesehatan yang mengacu kepada UU dan Permenkes No. 43 Tahun 2016 tentang Standar Pelayanan Minimal Bidang Kesehatan, agar dapat memberikan acuan bagi RS yang bekerja dalam memberikan pelayanan kepada masyarakat. Peraturan Daerah (Perda) ini pun dapat memberikan jaminan perlindungan hukum bagi pasien yang berobat di poli rawat jalan di RS.

Kab. Bogor tidak memiliki Peraturan Daerah tentang standar pelayanan minimal bidang kesehatan, namun demikian dengan adanya Permenkes No. 43 Tahun 2016, pengaturan tentang SPM Bidang Kesehatan ini harus tetap terlaksana. Pelaksanaan SPM rawat jalan di Kabupaten Bogor belum berjalan dengan baik, karena tidak mengacu pada Permenkes dan sepertinya masih harus menunggu hadirnya Peraturan Daerah. Yang seharusnya tidak demikian.

2. Faktor-faktor yang mempengaruhi pelaksanaan standar pelayanan minimal rawat jalan di Kabupaten Bogor.

Dinas Kesehatan :

a. Faktor Birokrasi.

1). Pemerintah Kabupaten Bogor melalui Dinas Kesehatan belum melaksanakan secara komprehensif Permenkes No. 43 Tahun 2016 tentang SPM Bidang Kesehatan, sehingga masih menggunakan Permenkes No. 56 Tahun 2014 tentang Klasifikasi dan Perijinan RS.

2). Dinas Kesehatan Kabupaten Bogor keliru memahami bahwa permenkes No. 56 tahun 2014 memiliki daya ikat yang kuat terhadap seluruh fasilitas kesehatan yang ada di indonesia.

b. Faktor Regulasi.

Sosialisasi Permenkes No. 43 Tahun 2016 tentang SPM Bidang Kesehatan di Kabupaten Bogor, belum dilaksanakan secar baik dan masih berpatokan dan mengacu pada permenkes no 56 tahun 2014. Rumah Sakit : kurang aktif mencari informasi mengenai 
peraturan Pemerintah terbaru, yaitu Permenkes No. 43 Tahun 2016 dan sumber daya manusia di rumah sakit masih belum mencukupi.

3. Pelaksanaan SPM Rawat Jalan di Kab. Bogor, belum berjalan dengan baik, karena tidak mengacu pada permenkes, dan masih harus menunggu hadirnya peraturan daerah yang seharusnya tdk demikian. Kurangnya SDM di RS dengan tipe C membuat pelayanan pasien menjadi terganggu dimana pasien semakin banyak yang membutuhkan pelayanan untuk kesehatan terutama di poli rawat jalan rumah sakit penelitian. Dalam hal ini jumlah SDM menjadi tidak imbang dengan jumlah pasien yang datang membutuhkan pelayanan di rumah sakit.

\section{SARAN}

1. Pemda Kabupaten Bogor : Untuk meningkatkan penajaman pelaksanaan Permenkes No. 43 tahun 2016 tentang SPM Bidang Kesehatan maka disarankan agar dibuat Peraturan Daerah (Perda) mengenai SPM Bidang Kesehatan di Kab. Bogor, agar menjadi acuan bagi pelayanan bidang Kesehatan di kabupaten Bogor. Agar dilakukan pelatihan-pelatihan mengenai SPM pada semua RS di Kab. Bogor sehingga Permenkes No. 43 Tahun 2016 Tentang SPM Bidang Kesehatan dapat dijalankan dengan baik.

2. Rumah Sakit : Dalam memberikan pelayanan kepada pasien selalu mengacu kepada peraturan terbaru, dan aktif berkoordinasi dengan Dinas Kesehatan akan adanya peraturan terbaru yang menjadi acuan dari pusat sehingga pasien merasakan pelayanan yang maksimal dalam pemenuhan haknya sebagai orang sakit. Menambah sarana untuk pelayanan sehingga kebutuhan pasien akan tempat tidur dapat terpenuhi. Menambah SDM yang melayani pasien yang datang membutuhkan pengobatan. Melakukan koordinasi dengan dokter pelaksana rawat jalan dimana waktu tunggu pasien di poli rawat jalan tidak lebih dari 60 menit, untuk meningkatkan kepuasan bagi pasien dalam pelayanan.

\section{DAFTAR PUSTAKA}

Abdul Wahab, Solichin, 2008, Analisis Kebijakan dari formula ke Implementasi Kebijaksanaan Negara, Jakarta : Pt. Bumi Aksara.

Adi, Rianto, 2005, Metodologi Penelitian Sosial dan Hukum, Jakarta: Granit.

Assaf, A.F. Al, 2009, Mutu Pelayanan Kesehatan : Perspektif Internasional, Jakarta : EGC.

Atmosudirdjo, Prajudi, 2008, Hukum administrasi Negara, Jakarta : Ghalia Indonesia.

Azizy, Ahmad Qodri Abdillah, 2007, Change Management Dalam Reformasi Birokrasi, Jakarta : Gramedia.

Azwar, Azrul, 1996, Menuju Pelayanan Kesehatan Yang Lebih Bermutu, Jakarta : Yayasan Penerbitan Ikatan Dokter Indonesia.

Dachi, Rachmat Alyakin, 2017, Proses dan Analisis Kebijakan Kesehatan, Yogyakarta : Deepublish.

Diantha, I Made Pasek, 2017, Metodologi Penelitian Hukum Normatif Dalam Justifikasi Teori Hukum, Jakarta : Prenada Media Grup. 
Efendi, Ferry dan Makhfudli, 2009, Keperawatan Kesehatan Komunitas : Teori dan Praktik dalam Keperawatan, Jakarta : Salemba Medika.

Fadjar, A. Muktie, 2005, Tipe Negara Hukum, Malang : Bayumedia Publishing.

Hadjon, Philipus. M, 2018, Administrasi Negara, Yogyakarta : Gajah Mada University Press.

Hadjon, Philipus. M, 2015, Perlindungan Hukum Bagi Rakyat Indonesia, Jakarta : Raja Grafindo Perkasa.

Hanafiah, M. Jusuf dan Amri Amir, 2008, Etika Kedokteran Dan Hukum Kesehatan, Jakarta : EGC.

Haris, Syamsuddin, 2014, Masalah-Masalah Demokrasi Kebangsaan Era Reformasi, Jakarta : Yayasan Pustaka Obor Indonesia.

Is, Muhamad Sadi, 2015, Etika Hukum Kesehatan, Jakarta : Prenada Media Grup.

Ismaniar, Hetty, 2015, Administrasi Kesehatan masyarakat, Yogyakarta: Deepublish.

Kansil, CST, 2011, Pengantar Ilmu Hukum dan Tata Hukum Indonesia, Jakarta: Rineka Cipta.

Kesuma, Silviani , 2015, The Ability Diagnostic Reading for Change, Yogyakarta : Deepublish.

Kurniawan, 2006, Manajemen Pelayanan Umum, Jakarta : Bumi Aksara.

Marbun, S. F, 2011, Peradilan Administrasi Negara dan Upaya Administratif di Indonesia, Yogyakarta: FH UII Press.

Marzuki, Peter Mahmud, 2005, Penelitian Hukum, Jakarta : Prenada Media.

Metrokusumo, Sudikno, 1999, Mengenal Hukum, Yogyakarta : Cahaya Tama Pustaka.

Muhtaj, Majda El, 2015, Hak Asasi Manusia Dalam Konstitusi Indonesia, Jakarta : Kencana.

Muntaha, H, 2017, Hukum Pidana Malapraktik Pertanggungjawaban dan Penghapus Pidana, Jakarta : Sinar Grafika.

Nasution, Bahder Johan, 2013, Hukum Kesehatan Pertanggungjawaban Dokter, Jakarta: Rineka Cipta.

Notoatmodjo, Soekidjo, 2010, Etika dan Hukum Kesehatan, Jakarta : Rineka Cipta.

R, Ridwan. H, 2013, Hukum Administrasi Negara, Jakarta : Rajawali Pers.

Rahardjo, Satjipto, 1996, Ilmu Hukum, Bandung : Citra Aditya Bakti.

Rahardjo, Satjipto, 2009, Hukum dan Perilaku, Jakarta : PT Kompas. Media Nusantara.

Rahardjo, Satjipto, 2010, Penegakan Hukum Progresif, Jakarta : PT Kompas Media Nusantara.

Riyadi, Alexander Lucas Slamet, 2016, Ilmu Kesehatan Masyarakat, Yogyakarta : Andi Offset.

Setiono, 2004, Rule of Law (Supremasi Hukum), Surakarta, Magister Ilmu Hukum Pascasarjana Universitas sebelas Maret.

Siswati, Sri, 2015, Etika dan Hukum Kesehatan Dalam Perspektif Undang-Undang Kesehatan, Jakarta : PT Raja Grafindo Persada.

Sinambela, Lijan Poltak, 2010, Reformasi Layanan Publik, Jakarta : PT. Bumi Aksara. 
Soekanto, Soerjono dan Sri Mamudji, 2010, Penelitian Hukum Normatif, Jakarta : Ghalia Indonesia.

Soemitro, Ronny Hanitijo, 1994, Metodologi Penelitian Hukum dan Jurimetri, Jakarta : Ghalia Indonesia.

Sumaryono, E, 2006, Etika Hukum Relevansi Teori Hukum Kodrat Thomas Aquinas, Yogyakarta: Kanisius.

Soeroso, R, 2017, Pengantar Ilmu Hukum, Jakarta : Sinar Grafika.

Sunggono, Bambang, 1997, Metodologi Penelitian Hukum, Jakarta : Rajagrafindo Perkasa.

Supriyadi, Wila Chandrawila, 2001, Hukum Kedokteran, Bandung : Mandar Maju.

Suwandi, 2015, Desentralisasi Fiskal, Dan Dampaknya Terhadap Pertumbuhan Ekonomi, Penyerapan Tenaga Kerja, Kemiskinan, Dan Kesejahteraan Di Kabupaten/Kota Induk Provinsi Papua, Yogyakarta : Deepublish.

Wiradharma, Dany 2008, Penuntun Kuliah Hukum Kedokteran, Malang : Bayumedia Publishing.

\section{Perundang-undangan}

Undang-Undang Dasar Republik Indonesia Tahun1945.

Undang-Undang No.29 Tahun 2004 Tentang Praktik Kedokteran.

Undang-Undang No.36 Tahun 2009 Tentang Kesehatan.

Undang-Undang No.44 Tahun 2009 Tentang Rumah Sakit.

Undang-Undang No.36 Tahun 2014 Tentang Tenaga Kesehatan.

Permenkes No. 11 tahun 2016 Tentang Penyelenggaraan Pelayanan Rawat Jalan Eksekutif Di Rumah Sakit.

Permenkes No.43 Tahun 2016 Tentang Standar Pelayanan Minimal di Bidang Kesehatan.

Keputusan Menteri Kesehatan No.129/Menkes/SK/II/2008 Tentang Standar Pelayanan Minimal Rumah sakit.

Undang-Undang No.23 tahun 2014 Tentang Pemerintahan Daerah.

\section{Internet}

Kemenkes RI, 2010, Rencana Strategis Kementerian Kesehatan Tahun 2010-2014, http://www.depkes.go.id.

Kemenkes, 2017, Kemenkes Tekankan pentingnya SPM Bidang Kesehatan, http://www.depkes.go.id.

Kemenkes RI, 2017, Inilah Perubahan Standar Pelayanan Minimal (SPM), http://www.depkes.go.id.

Dinas Kesehatan Kabupaten Bogor, 2013-2018, Renstra Dinas Kesehatan 2013-2018 Pemerintah kabupaten Bogor ,http://www.bogorkab.go.id. 